\title{
CHỦ QUAN TÍNH VÀ KHÁCH QUAN TÍNH TRONG HỆ THỐNG XU'NG HÔ VIẸT VÀ ANH
}

\author{
Nguyễn Quang* \\ Trương Đại học Ngoại ngũu, ĐHQGHN, Phạm Văn Đồng, Cầu Giấy, Hà Nội, Việt Nam \\ Nhận bài ngày 19 tháng 12 năm 2017 \\ Chỉnh sửa ngày 17 tháng 01 năm 2017; Chấp nhận đăng ngày 19 tháng 01 năm 2018
}

Tóm tắt: Bài viết đưa ra các định nghĩa công cụ về chủ quan tính và khách quan tính, trình bày về các hình thức/cặp xưng hô trong ngôn ngữ xét theo hệ hình T-V. Trên cơ sở nguồn nguyên cấp và thứ cấp, bài viết đi sâu phân tích các biểu đạt của chủ quan tính-khách quan tính trong hệ thống xưng hô Việt và Anh.

Tù khóa: chủ quan tính, khách quan tính, hình thức/cặp xưng hô, quan hệ xưng hô

\section{1. Đặt vấn đề}

Một điều cần được làm rõ trước khi xét hệ thống xưng hô Việt và Anh theo bình diện phạm trù này (cũng như các bình diện phạm trù khác) là chúng tôi hoàn toàn không có ý định đối lập các nét tính cách của những thành viên thuộc hai cộng đồng ngôn ngữ-văn hóa được xét trong hoạt động giao tiếp và khẳng định rằng các thành viên của cộng đồng $\mathrm{A}$ là tuyệt đối thế này (ví dụ: chủ quan, gián tiếp, nú tính...) còn các thành viên của cộng đồng B là tuyệt đối thế kia (ví dụ: khách quan, trục tiếp, nam tính...). Ngoài ra, chủ quan tính hay khách quan tính cũng chỉ là những khái niệm động và tương đối, không thể định vị được các điểm cùng cực (extreme end-points) và điểm phân cách (separating point). Trong hoạt động giao tiếp thực tế, tuyệt đại đa số các hành vi (cả ngôn tù và phi ngôn tù̀) chỉ có thể được đa số thành viên của một cộng đồng cảm nhận hay công nhận là thiên hơn về chư quan tính hay khách quan tính, trục tiếp hay gián tiếp, duy cảm hay duy lí,... dựa trên tổng hiệu quả của hành vi đó cũng như dựa trên các trải nghiệm của bản thân và các ẩn tàng văn hóa của cộng đồng đó.

\footnotetext{
*ĐT.: 84-936048670

Email: ngukwang@yahoo.com
}

Do vậy, chúng tôi cho rằng, với việc nghiên cứu các biểu đạt của chủ quan tính và khách quan tính trong hệ thống xưng hô Việt và Anh, ta chỉ có thể đi đến những nhận xét sơ khởi, chứ không phải những kết luận đóng khung (framed) và mang tính khuôn mẫu (stereotypical), rằng trong một/những tương tác cụ thể ở thời điểm nghiên cứu, đa số người thuộc cộng đồng A hình như thiên hơn về nét tính cách này còn đa số người thuộc cộng đồng $\mathrm{B}$ có xu hướng thiên hơn về nét tính cách kia. Thực tế nghiên cứu thực nghiệm cũng đã cho thấy, trong một số tình huống đặc thù, cái vốn được coi là thuộc tính của cộng đồng ngôn ngữ-văn hoá này nhiều khi lại được cộng đồng ngôn ngữ-văn hoá kia thể hiện với tỉ lệ cao hơn.

\section{Chủ quan tính và khách quan tính là gì?}

'Chủ quan tính' (Subjectivity) có thể được diễn giải là:

- Tính chất của việc phán xét dựa chủ yếu vào các ấn tượng cảm tính và quan điểm cá nhân chứ không phải vào thực tế ngoại tại.

- Tính chất của cách nhìn nhận, quan điểm, cảm nhận, đức tin, và mong ước của một người. Nó thường được sử dụng để hàm chỉ các quan điểm cá 
nhân, đối lập với kiến thức và các đức tin dựa trên thực tế.

- Tính chất của điều xẩy ra trong trí não và được điều chỉnh bởi định kiến cá nhân.

- Tính chất thuộc về chủ thể đối lại với khách thể (chủ thể là người tiếp nhận và nhận thức; khách thể là đối tượng được tiếp nhận hay đối tượng được chủ thể nhận thức).

- Phẩm chất phát xuất và tồn tại trong trí não của chủ thể tiếp nhận và không nhất thiết phải tương thích với bất cứ khách thể nào bên ngoài trí não.

Trong giao tiếp, 'Chủ quan tính’ được xác định là bản chất và đặc tính của nhũng hành vi, sư việc, tuoong tác chịu ảnh huởng của tình cảm, thái độ và chính kiến cá nhân.

'Khách quan tính' có thể được hiểu là:

- Tính chất của việc phán xét dựa vào thực tế và các hiện tượng có thể quan sát được và không chịu tác động bởi quan điểm, đức tin, cảm xúc hay định kiến cá nhân.

- Nỗ lực nắm bắt bản chất khách thể được xem xét theo cách không phụ thuộc vào bất kì đặc điểm nào của chủ thể nghiên cứu nó.

- Cách miêu tả về chất và lượng của các hiện tượng luôn không thay đổi khi các hiện tượng đó được quan sát trong các điều kiện khác nhau.

- ...

Trong giao tiếp, 'Khách quan tính' được hiểu là bản chất và đặc tính của nhũng hành vi, sư việc, tuoong tác không bị ảnh hưởng bởi tình cảm, thái độ và chính kiến cá nhân.

\section{Hình thức/Cặp xung hô trong các ngôn ngữ}

Hình thức/Cặp xưng hô, ngoài chức năng định diện các thành viên tham gia tương tác, là một phương tiện rất hữu hiệu để các đối tác giao tiếp biểu lộ thái độ, tình cảm của mình. Nói cách khác, các biểu đạt của chủ quan tính và khách quan tính, thông qua việc sử dụng các hình thức/cặp xưng hô trong các nền văn hoá, các tiểu văn hoá, các nhóm xã hội, các tình huống và sự kiện giao tiếp cụ thể... đều được thể hiện rõ nét.

Hình thức xưng hô (address forms, addressing forms, addressing terms, terms of address)/Cặp xưng hô (addressing dyads, addressing relationships) trong các ngôn ngũ cùng tính đa dạng, đa dụng, đa biểu thái của chúng là một hiện tượng thú vị trong nghiên cứu giao tiếp liên/giao văn hoá (Nguyễn Quang, 1992; Hughson, 2009; Szyman'skaMatusiewicz, 2014 ...). Có rất nhiều hệ thống xưng hô khác nhau trong các cộng đồng ngôn ngữ-văn hoá khác nhau: có những hệ thống đơn trục và đa trục, có những hệ thống thể hiện rõ tính dân chủ và bình đẳng trong quan hệ giao tiếp; có những hệ thống mang nặng mầu sắc tôn ti, gia trưởng và thừa kế quyền sinh (birthright inheritance); có những hệ thống mà trong bản thân chúng đã khu biệt đầy đủ tuổi tác, giới tính, địa vị, thái độ, tình cảm ...; và thậm chí, có cả những hệ thống toát lên mạnh mẽ ý niệm hiện sinh và đậm đặc tính chủ quan nội sinh. Ở một ngôn ngữ của thổ dân da đỏ, trong ba phát ngôn:

- Tôi chuyện trò với vợ sau bũa ăn.

- Tôi đang săn báo.

- Tôi sinh hoạt chăn gối với vọ. trong đó TÔI đều đóng vai trò chủ ngữ, và chủ thể của các phát ngôn đều đang nói chuyện với cùng một đối tác giao tiếp trong cùng một tình huống giao tiếp, nhưng hình thức xưng hô TÔI lại được thể hiện bằng ba cách hoàn toàn khác nhau, thể hiện cách nhìn nhận vừa mang tính chủ quan vừa mang tính hiện sinh của người nói. Theo cách nhìn nhận của người bản ngữ, ba 'thằng' TÔI này hoàn toàn không giống nhau. Khi TÔI chuyện trò với vợ sau bữa ăn, TÔI mang tâm trạng thư thái, bình an. Lúc TÔI săn báo, TÔI phải tập trung sự chú ý vào con mồi và mang tâm trạng căng thẳng. Còn khi TÔI sinh hoạt chăn gối với vợ, phần 'con' trong TÔI trỗi dậy, TÔI tắm mình vào thú vui nhục dục: TÔI là mãnh thú. Cả 
ba 'thằng' TÔI này hoàn toàn khác nhau, có chăng chúng chỉ trú chung trong một cái xác, một chủ thể hữu sinh hữu tử, hữu hình hữu hoại mà những người sử dụng các ngôn ngữ khác trong các nền văn hoá khác gọi là TÔI mà thôi.

Trong tiếng Nga, tiếng Pháp và nhiều ngôn ngữ Âu châu khác, xét theo chủ quan tính, khi trò chuyện với người khác và muốn tỏ thái độ lịch sự (âm tính) và trang trọng, người ta sử dụng các cặp, kiểu như: Я-BЫ và JE-VOUS. Khi quan hệ giữa hai người ở mức thân thiết, hoặc khi nói chuyện với trẻ nhỏ, hay lúc giận dữ, người ta sử dụng cặp tục thân Я-TЫ và JE-TU. Tiếng Anh trước đây cũng có hiện tượng này:

Xét theo lịch đại, tiếng Anh vốn cũng có hai hình thức đại tù̀ nhân xung ngôi thu' 2: 'Thou/Thy/Thee' chi số it và mang tính thân mạt, và 'Ye/Your/You'chỉ số nhiều và mang tính trang trong. Theo thòi gian, 'Ye' bị 'You' thay thế trong hệ hình của chính minh và 'You' cũng thay thế toàn bộ hệ hình 'Thou'.

(Nguyễn Quang, 1992: 36)

Do vậy, xét theo đồng đại, trong tiếng Anh chỉ còn tồn tại hệ hình 'You/Your/You' mang tính khách quan và phi biểu thái cao mà thôi. Tuy nhiên, cũng không nên nhận định một cách giản đơn rằng trong quan hệ xưng hô, tiếng Anh chỉ có cặp I-YOU mà thôi (chúng tôi sẽ bàn sâu về vấn đề này ở phần sau).

Khi nghiên cứu về hình thức xưng hô và những biểu đạt chủ quan tính của chúng, Brown và Gilman (1962) đã chỉ ra rằng việc sử dụng cặp nhân xưng I-YOU (và các hình thức tương đương) được qui định bởi hai yếu tố mà họ gọi là 'ngữ nghĩa Quyền lực' và 'ngữ nghĩa Thân hữu' (Power semantic and Solidarity semantic).

Fasold (1990: 3) đã làm sáng tỏ hai khái niệm này. Theo tác giả,

[...] ngũ nghĩa đại tù̀ chỉ quyền lực không mang tính có đi có lại, và điều trở thành lệ thói cố định trong bất cú cuộc hội thoại xã hội (và thậm chí gia đình) nào là người có quyền lưc thấp hơn sẽ phải dùng ' $V$ ' (đại tù̀ chỉ sư tôn trong trong bất cú ngôn ngũu nào, lấy tì chũ đầu của tì̀ Latin 'VOS') để gọi nguời có quyền lưc cao hơn, và đến luợt mình, anh ta sẽ nhận được 'T' (đại tù̀ thân mật tì̀ tiếng Latin ' $T U$ ').

Wardhaugh (1986: 262) nêu ra một loạt yếu tố tác động đến việc chọn lựa các hình thức xưng hô trong các ngôn ngữ nói chung. Theo ông,

[...] một loạt nhũng yếu tố xã hội luôn chi phối việc lựa chọn các hình thức [xưng hô - Ng. Q.] của chúng ta: mọt dịp nhất định nào đó; địa vị hoặc đẳng cấp xã hội của nguời khác; giới tính; tuổi tác; quan hẹ gia dình; tôn ti trong nghề nghiệp; hoàn cảnh giao dịch (vi dụ: môt cuộc gặp trong hoạt động dịch vu, hoạc quan hệ bác sĩ - bệnh nhân, hay quan hệ tu sĩ - con chiên); chủng tộc; hoạc mức độ thân mạt. Sư lự chọn đôi lúc tỏ ra rất rõ ràng: trong xã hội, khi nguồn gốc chủng tộc hoạc đẳng cấp đóng vai trò quan trọng, điều này dễ có co được chú ý hơn; khi các quan hệ gia đình tỏ ra thật sụ mạnh mẽ, điều kia dễ có khả năng đurọc coi trong hon; v.v.

Khi xem xét về ngữ nghĩa 'Quyền lực', ta dễ dàng chấp nhận rằng, xét về mặt xã hội, người nhiều tuổi hơn thường có quyền lực đối với người ít tuổi hơn, và ở một số xã hội, nam giới thường có quyền lực đối với nữ giới, trong khi ở một số xã hội khác, nữ giới lại có quyền lực đối với nam giới. Một số yếu tố khác cũng ít nhiều tác động đến ngữ nghĩa 'Quyền lực' của việc sử dụng hình thức xưng hô, song có thể vì chưa được quan tâm hay vì một lí do tế nhị nào đó mà chưa được đề cập. Đó là: Trình độ kiến thức và bằng cấp (trong kiểu xã hội Sĩ-Nông-Công-Thương), khả năng kinh tế, vật chất (trong kiểu xã hội Thương-CôngNông-Sĩ), sức mạnh cơ bắp trong những tình huống đặc thù, v.v. Tóm lại, theo chúng tôi, quyền lực xã hội trong các tương tác liên nhân 
bao gồm 6 loại chính yếu sau: quyền lực địa vị (status power), quyền lực tuổi tác (age power), quyền lực giới tính (gender power), quyền lực trí tuệ (intellectual power), quyền lực kinh tế (economic power) và quyền lực thể chất (physical power). Trật tự ưu tiên (order of priority) và sự thỏa hiệp của các loại quyền lực này tùy thuộc vào các chu cảnh tình huống và chu cảnh văn hóa cụ thể.

Đối với hệ thống xưng hô trong các ngôn ngữ Âu châu nói chung, có hai điểm cần chú ý về mặt nguồn gốc và hiện trạng. Về nguồn gốc,

Vì hình thức ' $V$ ' đurợc đura vào $x a ̃$ họi Âu châu tù̀ trên xuống, nên hình thức này gắn liền với các giai tầng qui phái, và nhũng ngườ quí phái vốn thuờng xung hô với nhau bằng hình thức ' $V$ '. Đối với dân thuờng, nhũng nguời đồng quyền (powerequals) vốn thuờng sủ dụng hình thức 'T' khi chuyện trò cùng nhau

(Fasold, 1990: 4)

Về hiện trạng (và điều này có lẽ đúng đối với xã hội Mĩ hơn là xã hội Anh và ở xã hội Anh, nó tỏ ra đúng đối với người trẻ tuổi hơn là người cao niên và trung niên),

Ngày nay chúng ta vẫn có thể thấy việc sủ dụng cặp $T / V$ một chiều, nhurng 'thân hưu' có $x u$ huoóng thay thế cho 'quyền lưc', do vậy, hiện nay ta thuờng thấy việc dùng 'T' qua lại trong các quan hệ mà trước đây vốn dùng yếu tố một chiều. Ví dụ: cha và con, ông chủ và người làm công.

(Wardhaugh, 1986: 252)

Hơn nữa, sự phân biệt về mức độ 'cái chung' (common ground) giữa mọi người, cái không chỉ đơn giản là có quyền lực tương đương, cũng trở nên không thể thiếu được trong bất cứ cộng đồng ngôn ngữ-văn hóa nào. Khái niệm 'Thân hữu' (Solidarity) mà theo Fasold (1990: 4) định nghĩa 'là sụ chia sẻ giũa mọi ngươi, một múc độ gần gũi và thân thiết' đã từ đó xuất hiện. Vì 'cái chung' có một vai trò quan trọng như vậy nên thường sẽ có một đối tác giao tiếp đề xuất việc sử dụng ' $\mathrm{T}$ ' trong xưng hô; và việc chuyển từ cách xưng hô $\mathrm{T} / \mathrm{V}$ một chiều sang hình thức ' $T$ ' qua lại đã được Brown và Gilman (1962: 260) giải thích như sau: Có một dấu tích thú vị về quan hệ quyền lưc trong quan niệm hiện thời; đó là quyền đề xuất việc sử dụng 'T' thuộc về thành viên của cặp giao tiếp có tu cách dụa trên quyền lục để dùng ' $T$ ' mà không cần tới sự có đi có laii. Việc gợi ra sư thân hũu [bằng cách sử dụng ' $\mathrm{T}$ '- $\mathrm{Ng}$.Q] tỏ ra tư nhiên hơn tù phía người cao tuổi đối với người thấp tuổi, tù phía người giầu hơn đối với người nghèo hơn, tù phía ông chủ đối với người làm công, tù̀ phía người quí phái đối với ngưòi bình dân, tù phía nũ đối vói nam.

Tuy nhiên, trong môi trường văn hoá Việt và trong thực tế sử dụng tiếng Việt, việc gợi ra sự thân hữu (nói cách khác là việc đề xuất sử dụng hình thức ' $T$ '), trong phần lớn các trường hợp, có lẽ đều xuất phát từ nam giới. Nên chăng, ta giải thích hiện tượng này như một biểu hiện của xã hội gia trưởng, trọng nam; và mặc dù không còn được chấp nhận về mặt pháp lí và xã hội, nhưng yếu tố 'trọng nam' này vẫn được cảm nhận khá mạnh mẽ trong cuộc sống nói chung và đời sống ngôn ngữ nói riêng.

Dẫu vậy, theo Brown và Gilman (1962), nếu hai đối thể giao tiếp bình đẳng về quyền lực nhưng không, hoặc chưa, có ý định đạt tới biểu đạt chủ quan tính của sự thân hữu thì trong giao tiếp, họ sẽ sử dụng hình thức ' $\mathrm{V}$ ' để xưng hô với nhau. Việc sử dụng này khác với kiểu sử dụng ' $\mathrm{V}$ ' qua lại của những người quí phái trước đây. Ngày nay, ' $\mathrm{V}$ ' được sử dụng qua lại giữa những người bình đẳng nhưng phi thân hữu thuộc mọi tầng lớp xã hội. Hình thức này trong tiếng Anh, Pháp, Đức... có thể tương đương với 'Quan hệ ngang-Loại II' trong tiếng Việt (sẽ được trình bày ở phần sau). Còn nếu hai đối thể giao tiếp cùng bình đẳng về quyền lực và đều muốn biểu đạt sự thân hữu, họ sẽ sử dụng ' $T$ ' qua lại dù họ thuộc tầng lớp 
xã hội nào. Hình thức này có thể thấy trong 'Quan hệngang - Loại I' ở tiếng Việt (sẽ được trình bày ở phần sau).

Tuy nhiên, khi xem xét loại hình $\mathrm{T}-\mathrm{V}$
Kết quả nghiên cứu của Nguyễn Quang (1999) về việc sử dụng hình thức/cặp xưng hô trong một hành động giao tiếp (communicative $a c t)$ cụ thể cho thấy:

Bảng 1. Lực ngữ dụng của hình thức/cặp xưng hô Việt và Mĩ

\begin{tabular}{|c|c|c|c|c|c|}
\hline $\begin{array}{r}\text { Lực } \\
\text { ngữ dụng }\end{array}$ & $\begin{array}{c}\text { Trung tính } \\
\text { (Neutrality) }\end{array}$ & $\begin{array}{c}\text { Tôn trọng } \\
\text { (Respect) } \\
\text { Thân và/hoặc tục } \\
\text { (Endearment and/or } \\
\text { vulgarism) }\end{array}$ & $\begin{array}{c}\text { Tôn trọng và } \\
\text { Thân mật } \\
\text { (Respect and } \\
\text { intimacy) }\end{array}$ & $\begin{array}{c}\text { Gia đình tính } \\
\text { (Familiality) }\end{array}$ \\
\hline Việt & 0 & $\begin{array}{c}\text { QHN-L II } \\
(13,99 \%)\end{array}$ & $\begin{array}{c}\text { QHN-L I (16,67\%) } \\
\text { AFA (16,27\%) }\end{array}$ & $\begin{array}{c}\text { QHĐ-L I } \\
(22,65 \%) \\
\text { QHĐ-L II (0\%) }\end{array}$ & $\begin{array}{c}\text { QHV } \\
\text { QHĐ-L III } \\
(0,94 \%)\end{array}$ \\
\hline Mĩ & I-YOU & $\begin{array}{c}\text { T (0,2\%) } \\
\text { TLN (1,45\%) } \\
\text { LN (0\%) }\end{array}$ & $\begin{array}{c}\text { FN (1,74\%) } \\
\text { MNs (0,38\%) } \\
\text { AFA (39,32\%) }\end{array}$ & 0 & $\begin{array}{c}\text { K/KFN } \\
(0,78 \%)\end{array}$ \\
\hline
\end{tabular}

trong hệ thống xưng hô nói chung do Brown và Gilman đưa ra, Muehlhaeusler và Harre (1990) cho rằng loại hình này là chưa thỏa đáng (unsatisfying) và dựa chủ yếu vào các hệ thống xưng hô trong các ngôn ngữ Tây Âu (Western European languages). Szyman'skaMatusiewicz (2014: 96) khẳng định rằng:

'Trong nhiều ngôn ngũ phi-Âu (nonEuropean languages), đặc biệt là các ngôn ngũ có nguồn gốc Đông $\dot{A}$ (được gọi là các ngôn ngũ 'Đông phuơng'), hệ thống xung hô phức tạp hơn rất nhiều, vuoọt ra ngoài sư phân biệt $T-V$. [...]. Mặc dù, trong nhiều ngôn ngũu, nguời ta có thể luu ý đến sự hiện diện của ngũ nghĩa trong các hệ thống xung hô, nhung trong các ngôn ngũ Đông $\dot{A}$, khuynh huóng sủ dụng các hình thức hàm chỉ nhân xung bạch nghĩa (semantically marked personreferring forms) tỏ ra mạh mẽ hơn nhiều. Trên thể liên tục (continuum) miêu tả tính bạch nghĩa của các hệ thống xung hô đặc thù, tiếng Việt có thể được miêu tả nhu một vi du rất điển hình của tính bach nghĩa, vì nó hoàn toàn thiếu vắng sư hiện diện của các hình thức hiển minh (nhu' 'I' trong tiếng Anh)'.
* (QHV: Quan hệ vòng; QHN-L I: Quan hệ ngang - Loại I; QHN-L II: Quan hệngang - Loại II; QHĐ-L I: Quan hệ động - Loại I; QHĐ-L II: Quan hệ động - Loại II; QHĐ-L III: Quan hệ động - Loại III; AFA: Nói trống không; T: Chức danh; TLN: Chức danh+Tên họ; LN: Tên họ; FN: Tên riêng; MNs: Đa danh; K: Danh tù thân tộc; KFN: Danh tù̀ thân tộc+Tên riêng)

Tần suất sử dụng của các hình thức/cặp xưng hô Việt và Mĩ xét theo 'lực ngữ dụng' (pragmatic force) trong hành động giao tiếp này gợi ra những nhận xét sau:

+ Trong khi khoảng cách giữa tỉ lệ sử dụng các loại quan hệ xưng hô trong tiếng Việt không lớn lắm (trừ $\mathrm{QHĐ-LII} \mathrm{và} \mathrm{QHĐ-}$ LIII), nói cách khác, các nghiệm thể Việt sử dụng các loại quan hệ xưng hô tương đối đa dạng, thì các nghiệm thể Mĩ lại chủ yếu tập trung vào hai loại: 'Cặp I-YOU' và 'Không sử dụng hình thức xưng hô' (AFA).

+ Trong khi ở tiếng Việt không tồn tại loại quan hệ xưng hô trung tính tương đương với cặp I-YOU trong tiếng Anh thì ở tiếng Anh lại hoàn toàn không có loại hình thức/cặp xưng hô đồng thời thể hiện sự tôn trọng và thân mật 
như 'Quan hệ động-loại I' và 'Quan hệ độngloại II' trong tiếng Việt.

+ Nếu với các nghiệm thể Mĩ, hình thức xưng hô trung tính được sử dụng với tỉ lệ cao nhất (Cặp I-YOU: 56,13\%) thì với các nghiệm thể Việt, quan hệ xưng hô gia đình tính lại có tỉ lệ sử dụng cao nhất (QHV: 29,48\%).

Robinson (1972: 129) đã đưa ra giả thuyết sau:

Trong các xã hội trong đó địa vị của một người được khẳng định thông qua nhũng thành tưu của người ấy thì trong cách thức xung hô it có sư phân biệt [biểu đạt chủ quan tính thấp do biểu thái, biểu cảm thấp]. $O$. nhũng xã hội này, người ta có thể chỉ sủ dụng một hinh thức xung hô co bản; ho dự vào nhũng phuoong tiện khác để diễn tả nhũng loại quan hẹ khác nhau mà chúng ta phải công nhận là vẫn tồn tại. Tuy nhiên, trong nhũng xã họi mà ơ đó địa vị được gán ghép, có nghĩa là ngay tù lúc sinh thành đã đurợc sắp đặt vào một nhóm xã hội nhất định nào đó, chúng ta rất dễ dàng có thể thấy đuợc những cặp hinh thức xung hô được sắp đặt một cách tinh tế [biểu đạt chủ quan tính cao do biểu thái, biểu cảm cao]. Các cặp đó phản ánh nhũng cấu trúc xã hộ của các xã

họi này.

Theo chúng tôi, đây là một giả thuyết rất đáng chú ý, song cần có những thực tế và số liệu điển hình, cả đồng đại và lịch đại, đi kèm. Khi xét đến giả thuyết này, ta dễ có cảm giác là loại hệ thống xưng hô thứ nhất có thể áp dụng vào các cộng đồng 'văn hóa trẻ', đặc biệt là Mĩ, Úc ..., còn loại thứ hai - vào các cộng đồng 'văn hóa già', đặc biệt là các cộng đồng Đông phương (Việt, Nhật, Hàn, Trung ...). Nếu quả vậy, một loạt câu hỏi sẽ được đặt ra:

- Ở nước Anh thời xa xưa, khi con người ngay từ lúc sinh ra đã được gán ghép vào một nhóm xã hội nhất định (birthright inheritance) thì trong tiếng Anh thời đó hệ thống xưng hô có thuộc loại thứ hai không? Và nếu có thì những yếu tố trực tiếp nào đã chuyển hệ thống xưng hô của tiếng Anh từ loại thứ hai sang loại thứ nhất?

- Trong tiếng Anh, tại sao 'ye' lại bị 'you' thay thế trong hệ hình của chính mình (ye) yourlyou) và toàn bộ hệ hình 'thou' (thou/thy/ thee) cũng chịu chung số phận? Phải chăng đây là hệ quả của quá trình cọ xát giữa tiếng Anh và các ngôn ngũ̃ của các quốc gia đã một thời xâm lấn nước Anh? Hay do những biến chuyển nội tại trong xã hội Anh quyết định? Hay tâm lí bảo thủ, hướng thượng, học theo cách sử dụng hình thức ' $\mathrm{V}$ ' của giới quí phái trong dân chúng Anh đã dẫn đến việc xoá bỏ hệ hình 'thou'; rồi lại do cách xưng hô gián tiếp mang sắc thái trang trọng, kiểu như: 'Your Majesty' (Vẻ-uy-nghi-của-Ngài: Muôn tâu bệ hạ), 'His Excellency'(Sự-xuất-chúng-củaông-ta: Thưa Ngài) mà 'ye’ đến lượt nó lại bị 'you' (vốn đóng vai trò bổ ngữ, vai trò gián tiếp) thay thế?

- Trong xã hội Việt truyền thống, cũng như ở nhiều xã hội Đông phương khác, hệ thống xưng hô được nhiều nhà nghiên cứu tin là thuộc loại hai và, ở các mức độ khác nhau trong những hoàn cảnh cụ thể, do 'thừa kế quyền sinh' (birthright inheritance) quyết định. Nhưng trong tương lai khi địa vị của một người ngày càng được khẳng định thông qua những thành tựu của người đó thì hệ thống xưng hô của tiếng Việt có vì thế mà chuyển sang loại một hay không? Hoặc có thể có sự tồn tại song song của hai hệ thống xưng hô trong tiếng Việt: một trong giao tiếp công việc và một trong đời sống thường nhật hay không?

- Cũng như nhiều đặc tính văn hoá khác (đặc biệt là các đặc tính văn hoá-ngôn ngữ) trong quá trình giao tiếp liên văn hoá đang ngày càng trở nên mạnh mẽ, hệ thống xưng hô nào tỏ ra tích cực và phù hợp hơn? Hệ thống nào sẽ chi phối và đồng hoá hệ thống nào? Và có xẩy ra cái mà ta gọi là 'sự toàn cầu hoá' 
(globalisation) của hệ thống thứ nhất hoặc thứ hai không?

Đây là những vấn đề rộng lớn và, hiện tại, chúng tôi không có khả năng và ý định đi sâu nghiên cứu với tư cách cá nhân. Những câu hỏi này được nêu ra chỉ nhằm gợi mở cho các nghiên cứu trong tương lai của bản thân và các đồng nghiệp có quan tâm.

Nói tóm lại, xét theo chủ quan tính, có một điểm trong cách thức sử dụng các hình thức/cặp xưng hô trong hầu hết các ngôn ngữ được nhiều nhà nghiên cứu tán đồng ở các mức độ khác nhau (Brown và Gilman, 1972; Bates và Benigni, 1975; Lambert và Tucker, 1976; Wardhaugh, 1986; Fasold, 1990; Muehlhaeusler và Harre, 1990; Nguyễn Quang, 1992; Hughson, 2009; Szyman'ska-Matusiewicz, 2014 ...). Đó là (Fasold, 1990: 7):

Có một sụ khác biệt đáng kể trong việc lưa chọ hình thưc xung hô dựa vào nhân thân của người nói. Điều này không chỉ đúng với các ngôn ngũu, mà thậm chí trong nội bộ một ngôn ngũ và một cônng đồng, tuỳ thuộc vào [...] tuổi tác, giới tính và các yếu tố xã hội khác của người nói.

\section{Chủ quan tính và khách quan tính trong hệ thống xưng hô tiếng Việt}

Khi nghiên cứu về các hệ thống xưng hô sử dụng 'danh từ thân tộc' (kinship terms), thể hiện tình cảm đồng nhóm, gia đình hóa và chủ quan tính, Wardhaugh (1986: 262) nhận xét:

Trong thưc tế, một số ngôn ngũ đã sư dụng cái mà chúng ta vốn nhìn nhận nhu các 'danh tù thân tộc'làm hình thức xung hô. [ ...] Mọt ví du [...] về truờng hơp này là tiếng Việt trong đó một người gọi nhũng ngườ khác bằng nhũng tù tuoong đương với các tù tiếng Anh 'uncle' (chú) bác), 'older sister' (chi), 'younger brother' (em trai) v.v. Thậm chí cái tuong đưong với đại tù 'I' (Tôi) của tiếng Anh cũng là 'danh tù thân tộc'. Do vâyy, trong bất cú và trong mọi quan hệxã hội, nhũng người nhập cuộc phải gắng tư phân loại và phân loại ngườ khác, và sủ dụng nhũng yếu tố nhu ho hàng, vị trí xã hồi và tuổi tác để chọn lựa tù xung hô cho thich hop.

Trong tiếng Việt, trước khi chuyện trò với người mới quen biết, người ta luôn có ý thức xem xét đối thể giao tiếp để ít nhiều đoán định tuổi tác, giới tính, vị trí xã hội... của người ấy, quan hệ giữa họ và người ấy, thái độ, tình cảm cần biểu hiện... nhằm sử dụng các cặp xưng hô phù hợp. Ở cộng đồng Việt, khi chuyện trò với người khoảng tuổi cha chú mình, người ta thường xưng 'cháu' (con) và gọi người kia là 'chú' (bác) (Phương ngũ Bắc). Ví dụ (1):

- Dạ, cháu mời bác lên gác. Bố cháu đang ở trên ấy ạ.

Nhưng khi nói chuyện với người khoảng tuổi con mình, người ta lại xưng 'bác' (chú) và gọi người kia là 'cháu' (con). Ví dụ (2):

- Cháu lên gác đi. Nam ở trên ấy đấy.

Kết quả khảo sát giao văn hóa của Nguyễn Quang (1992: 45) cho thấy:

Khi giao tiếp với một người nào đó có 'Quyền lục địa vị và/hoặc tuổi tác' (Age and/or status power) cao hơn, người Việt có xu huoóng sử dụng cả hai hình thức xưng hô của cặp [như trong ví dụ (1)-Ng.Q], thậm chí cả trong câu cầu khiến (imperatives), và điều này hiếm khi xảy ra trong tiếng Anh. Nhung khi chuyện trò với người có quyền lực thấp hơn, ho có thể không cần sủ dụng tới hình thức xung hô tuoong duơng với 'I' trong tiếng Anh [như trong ví dụ (2)-Ng.Q]. Người Việt có lẽ ý thức được rằng sư tôn trong và tình thân hũu với đối tác giao tiếp có thể được thể hiện rõ ràng khi cặp tuoong đuoong với I-YOU (vi du: cháu-bác) đuoơcc sủ dụng đầy đư; và tình cảm thân mật cùng sự gần gũi có thể dễ dàng đạt được khi cặp này (ví dụ: 
bác-cháu) bị khuyết đi một vế (và dĩ nhiên, đó sẽ là hình thức nhân xung 'bác' thuộc ngôi thư nhất vốn gơi lên tính bề trên).

Nguyễn Tài Cẩn (1975) khẳng định rằng các danh từ thân tộc trong tiếng Việt phong phú hơn (và do vậy, có thể suy diễn một cách máy móc là khả năng biểu đạt chủ quan tính cũng cao hơn, tinh tế hơn (?) - Ng.Q) so với tiếng Anh, tiếng Pháp, tiếng Nga... bởi trong hệ thống danh từ thân tộc tiếng Việt có:

a. Sự phân biệt giữa địa vị trên và địa vị dưới:

$\underline{B a ́ c} ; \underline{A n h} ; \underline{C h i}$

Chú Em Em
Quan sát cá nhân cùng các kết quả nghiên cứu của chúng tôi và đồng nghiệp có xu hướng thiên về nhận định rằng, trong giao tiếp xã hội, các cặp danh từ thân tộc dùng trong xưng hô tỏ ra rất tích cực, và trong thực tế, chúng hầu nhu lấn át các kiểu quan hệ xưng hô khác như 'Quan hệ ngang-loại I', 'Quan hệ ngang-loại II', 'Quan hệ động-loại I', 'Quan hệ động-loại II' và 'Quan hệ động-loại III’ (sẽ được trình bày tiếp sau). Tuy nhiên, không phải tất cả các cặp danh từ thân tộc đều được sử dụng rộng rãi trong giao tiếp xã hội. Kết quả khảo sát của Nguyễn Quang (1992) cho thấy: Trong số 562 lượt trả lời, có tới 428 lượt sử dụng các hình thức xưng hô vốn là danh từ thân tộc, nhưng chủ yếu tập trung vào các cặp sau:

Trong khối liệu, chỉ thấy sự xuất hiện

\begin{tabular}{|c|c|c|}
\hline \multirow{2}{*}{ SỐ THỨ TỤ' } & \multicolumn{2}{|c|}{ DANH TƯ' THÂN TỘC } \\
\hline & CHỦ THỄ & ĐỐI THỄ \\
\hline 1 & Cháu/Con & $\mathrm{Cu}$ \\
\hline 2 & Cháu/Con & Ông \\
\hline 3 & Cháu/Con & Bà \\
\hline 4 & Cháu/Con & Bác \\
\hline 5 & Cháu/Con & Chú \\
\hline 6 & Cháu/Con & Cô \\
\hline 7 & Em & Anh \\
\hline 8 & Em & Chị \\
\hline 9 & Anh & Em \\
\hline 10 & Chị & Em \\
\hline 11 & Cô & Cháu/Con \\
\hline 12 & Chú & Cháu/Con \\
\hline 13 & Bác & Cháu/Con \\
\hline 14 & Ông & Cháu/Con \\
\hline 15 & Bà & Cháu/Con \\
\hline
\end{tabular}

b. Sự phân biệt giữa bên nội và bên ngoại:

$$
\frac{B a ́ c-C h u ́}{C a ̣ ̂ u} ; \frac{C o ̂}{D i}
$$

c. Sự phân biệt giữa họ hàng máu mủ và họ hàng do hôn nhân:

$$
\frac{\text { Bác-Chú-Câu }}{\text { Dương }} ; \frac{C \hat{o}-D i ̀}{\text { Thím-Mọ }}
$$

của cặp 'Cháu/Con (người nói)-Cu (người nghe)' mà không thấy sự hiện diện của cặp ' $C u$ (người nói)-Cháu/Con (người nghe)'. Ngay cả khi tác giả nêu rõ tuổi tác của các đối tác giao tiếp: Người nói khoảng 80 tuổi và người nghe khoảng 15 tuổi (có nghĩa là 
khả năng cho sự xuất hiện cặp 'Cu-Cháu/ Con' đã được mở), nhưng các nghiệm thể cũng chỉ sử dụng tới cặp 'Ông-Cháu/Con' và 'Bà-Cháu/Con', trong đó khá nhiều người bỏ vế thứ nhất $(\hat{O} n g / B a ̀)$ của cặp. Điều này, phải chăng, có thể được giải thích bởi sự khiêm nhường (một giá trị tích cực trong văn hoá Việt) của người Việt?

Một hiện tượng nữa có thể quan sát được là, trong trường hợp người nghe hoặc người nói ở độ tuổi xấp xỉ với cha mẹ của người nói hoặc người nghe thì trong phương ngữ Bắc thường xuất hiện cặp 'Cháu/Con-Chú/Cô' hay 'Chú/ Cô-Cháu/Con' chứ không phải là 'Cháu/ConDì/Cậu/Dượng' hay 'Dì/Cậu/Dượng-Cháu/ Con'. Nên chăng ta hiểu đây là một biểu hiện của ý thức phụ hệ và khuynh hướng "thiên nội" trong gia đình và văn hoá Việt ở phía Bắc?

Các danh từ thân tộc được sử dụng trong xưng hô xã hội mang tính chủ quan và biểu cảm cao có thể tạo ra một loại quan hệ mà chúng tôi xin được gọi là 'Quan hệ vòng' (Circular Relationship/ Category). Quan hệ này được biểu diễn ở sơ đồ sau (trong sự so sánh với cặp I-YOU khách quan, trung tính trong tiếng Anh):

Loại quan hệ này được sử dụng rộng rãi trong giao tiếp gia đình và xã hội nhằm diễn tả tính bất bình đẳng (inequality), tôn trọng (dưới đối với trên), thân mật (trên đối với dưới), và thân hữu (solidarity).

Ngoài loại 'Quan hệ vòng', trong tiếng Việt cũng tồn tại những cặp xưng hô không phải là danh từ thân tộc, nhưng vẫn thể hiện chủ quan tính cao. Mặc dù chúng được sử dụng để diễn tả tính bình đẳng về địa vị và/ hoặc tuổi tác và dễ bị/được qui kết là mang tính khách quan, nhưng Nguyễn Quang (1992:50) cũng lưu ý:

... cũng cần nhớ rằng nhũng đối tác giao tiếp (interlocutors) sủ dụng các cặp này thường là nhũng người "đồng quyền"(power equals) vàl hoặc muốn biểu lộ tình cảm thân mật và tính đồng nhóm (in-group identity). Các cặp này phần lớn được nhũng người trẻ tuổi, bạn bè hay ban hoc cũ, bạn xua sủ dung.

Vì ở đây xuất hiện sự ngang bằng trong quan hệ xưng hô, nên chúng tôi gọi kiểu quan hệ này là 'Quan hệ ngang-loại I' (Horizontal Relationship-Type I hoặc Horizontal Category I) được sử dụng để diễn tả sự bình đẳng, tình thân hữu và/hoặc tính tục thân.

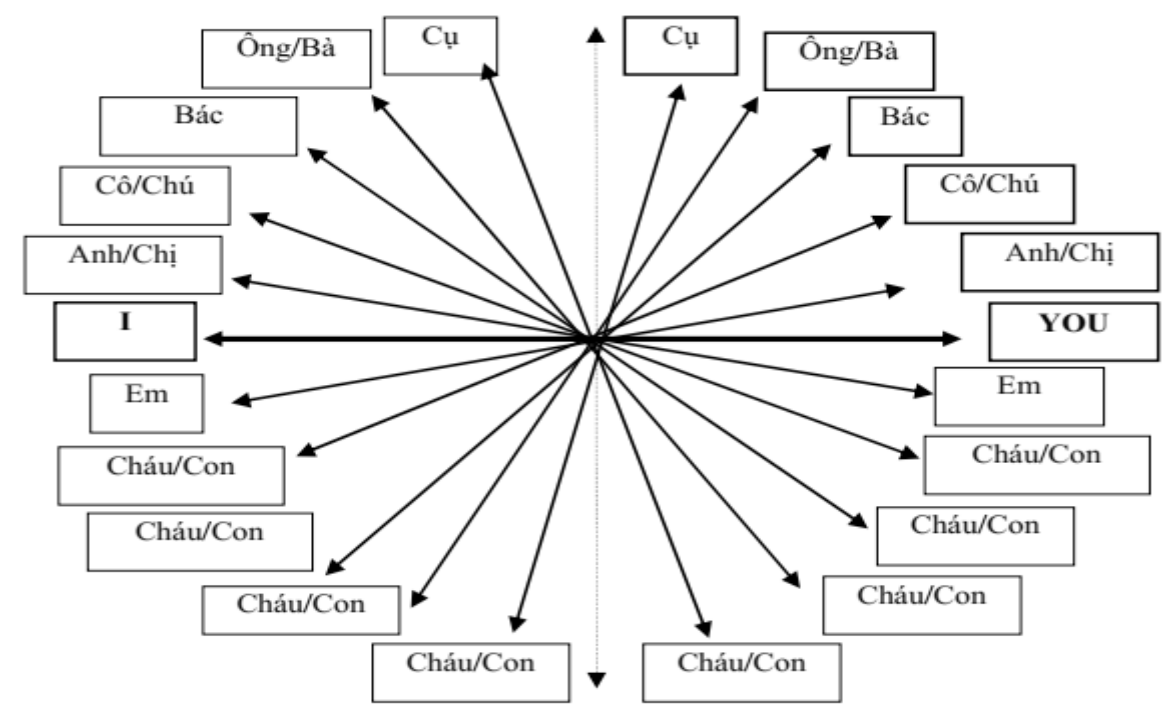

Hình 1. Quan hệ vòng của danh từ thân tộc tiếng Việt trong xưng hô 


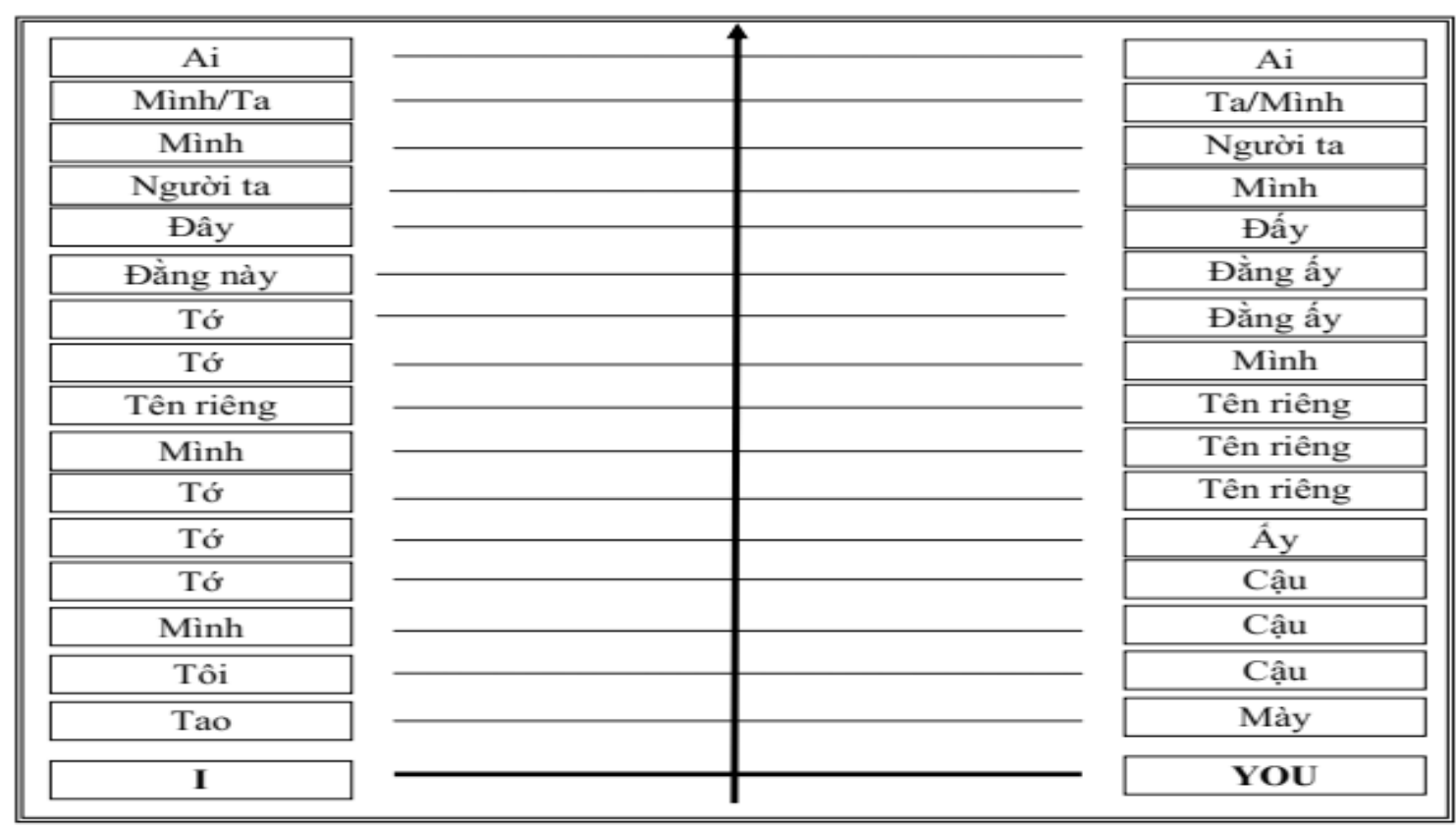

Hình 2. Quan hệ ngang-loại I của hình thức xưng hô trong tiếng Việt

Cũng như trường hợp 'Đa danh' (Multiple names) của tiếng Anh (sẽ được trình bày ở phần sau), việc sử dụng những cặp xưng hô này rất tinh tế và tỏ ra rất khó đối với người Âu-Mĩ khi tiếp xúc với tiếng Việt. Ngay cả việc sắp xếp chúng theo mức độ bình đẳng (equality), thân hữu (solidarity) và thân mật (intimacy) cũng chỉ mang tính tương đối.

Xét theo chức năng biểu thái của chủ quan tính, 'Quan hệ ngang-loại I', ở một mức độ đáng kể, đóng vai trò tương đương với hình thức ' $T$ ' (thân mật) qua lại trong các ngôn ngữ Ân-Âu. Tuy nhiên, vấn đề cần thấy ở đây là, trong khi hình thức ' $\mathrm{T}$ ' qua lại được sử dụng khá rộng rãi trong ngôn ngữ-văn hoá Anh-MĩÚc, không kể tuổi tác, giới tính, địa vị, nghề nghiệp... thì 'Quan hệ ngang-loại I' lại có phạm vi và tần suất sử dụng hạn hẹp hơn: Chủ yếu tập trung ở những người trẻ tuổi, bạn bè thân hữu, bạn học cũ hay bạn xưa. Cặp xưng hô Tao-Mày, mặc dù thường bị coi là tục, nhưng không phải lúc nào cũng tục và chỉ được sử dụng để diễn tả sự giận dữ hay khinh bỉ. Nhiều khi, nó dược dùng như những hình thức xưng hô rất thân mật trong 'Quan hệ ngang-loại I' và có thể tương đương với cặp 'JE-TU' trong tiếng Pháp và ' $Я$-TbI' trong tiếng Nga.

Ngoài kiểu 'Quan hệ ngang-loại I', trong tiếng Việt còn tồn tại một kiểu quan hệ ngang khác mà chúng tôi xin được gọi là Quan hệ ngang-loại II' (Horizontal Relationship-Type II hoặc Horizontal Category II). Loại quan hệ này có thể được coi như tương đương với việc sử dụng ' $V$ ' (Tôn trọng) qua lại trong các ngôn ngữ Ấn-Âu vì các cặp trong loại quan hệ này diễn tả sự bình đẳng tương đối, tính trang trọng và tính phi thân hữu (insolidarity). Đồng thời, nó cũng được coi là loại quan hệ xưng hô mang tính biểu thái thấp nhất và, do vậy, có tính khách quan cao nhất trong hệ thống xưng hô Việt. 


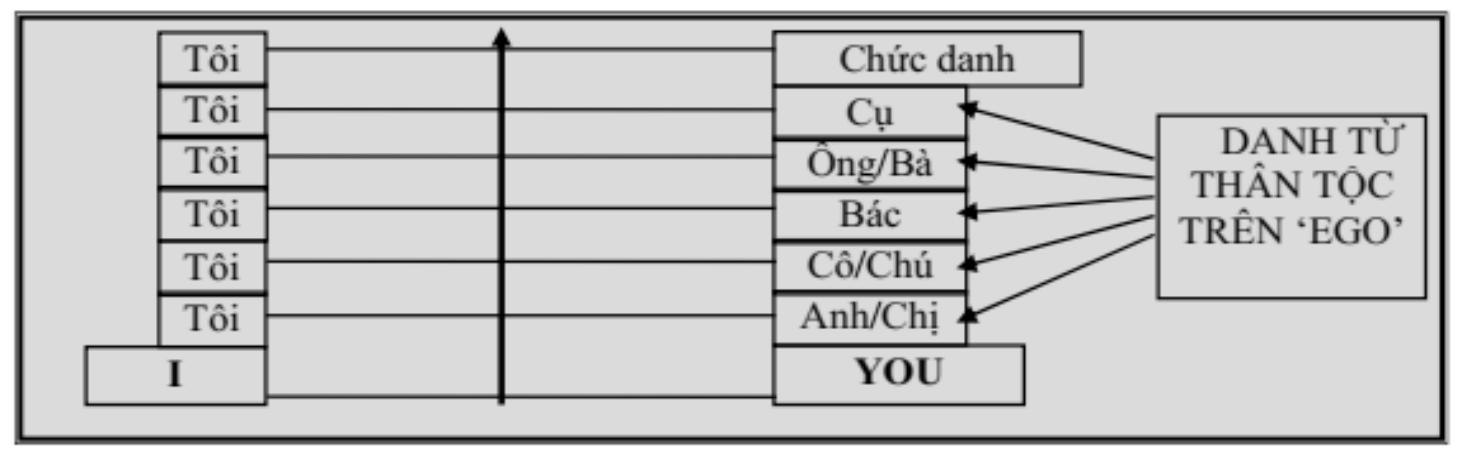

Hình 3. Quan hệ ngang-loại II của hình thức xưng hô trong tiếng Việt

Tuy nhiên, Nguyễn Quang (1992: 51) nhận xét rằng:

... xét về lịch đại và tù̀ nguyên, nhũng hình thức này vốn không phải bình đăng, vì TÔI theo nghĩa gốc có nghĩa là 'bầy tôi' (trong quan hệ với Vua) và cu, ông, bà, bác, chú, cô, anh, chị đều là danh tù thân tộc thuộc địa vị cao hon so với 'ego' (bản thân). Nhung xét theo đồng đại và dụng học, nhũng cặp này được sủ dung đơn giản là để diễn tả sụ bình đẳng, lịch sư, nhún nhường và phi thân hữu.

Một điểm cần lưu ý ở loại quan hệ này là mặc dù các danh từ thân tộc 'Anh-Chị' trên lí thuyết và xét theo quan hệ thứ bậc thuần tuý là thấp hơn so với các danh từ thân tộc ' $C o ̂$ Chú', nhưng khi được sử dụng trong loại quan hệ này và xét theo chủ quan tính và hiệu lực ngôn tác của phát ngôn mà trong đó cặp 'Tôi$C o ̂ / C h u '$ ' và 'Tôi-Anh/Chị' xuất hiện thì cặp trước (Tôi-Cô/Chú) mang tính thân hữu cao hơn. Ví dụ:

- Chú cú nói thế chư nếu chú mà dụ thi thì điểm cao hơn tôi là cái chắc.

Richards và Sukwiwat (1986: 137) nhận xét rằng:

Trong xã hội Nhật và Thái [...] mức độ quyền lực do tuổi tác và nghề nghiẹp tạo ra cao hơn so vói xã họi
Mĩ. Điều này có nghĩa là trong hoạt động giao tiếp ở tiếng Nhật và tiếng Thái, đối với các cặp người lón tuổi hơn - người nhỏ tuổi hơn, giáo su - sinh viên, hoạc bác sĩ - thu ki [y sĩ ghi chép cho bác sĩ-Ng.Q], thành viên thứ nhất của tùng cặp giũ một mức độ quyền lực quan hệ cao hơn so với mức độ mà ngưòi áy nắm giũ trong xã hội Mĩ [...]. Sinh viên Mĩ [...] đôi lúc goi giáo su bằng tên riêng, một tình huống không xuất hiện ở Nhật hay Thái Lan.

Có lẽ nhận xét này cũng đúng khi ta quan sát và so sánh xã hội Việt với xã hội Mĩ.

Trong xã hội Việt, nếu có sự đụng độ giữa quyền lực tuổi tác và quyền lực địa vị, có nghĩa là người lớn tuổi hơn có địa vị nghề nghiệp thấp hơn, thì, không như trong xã hội Mĩ ở đó địa vị đóng vai trò quan trọng hơn trong việc quyết định hình thức xưng hô, trong tiếng Việt sẽ xuất hiện sự thoả hiệp trong cách thức sử dụng hình thức xưng hô. Người có địa vị thấp hơn nhưng nhiều tuổi hơn có xu hướng xưng 'Tôi' và gọi người kia bằng 'Chức danh' để biểu thị sự tôn trọng và thể hiện tính phi biểu thái. Còn người có địa vị cao hơn nhưng ít tuổi hơn có xu hướng xưng 'Tôi' và gọi người kia là bác, anh, chị... (tuỳ theo khoảng cách tuổi tác giữa họ) với cùng một mục đích.

Bảng 2. Sự thoả hiệp xung đột giữa quyền lực tuổi tác và quyền lực địa vị trong xưng hô tiếng Việt

\begin{tabular}{|c|c|c|}
\hline Người đối thoại & I & You \\
\hline Nhiều tuổi hơn nhưng địa vị thấp hơn & Tôi & Chức danh \\
\hline Ít tuổi hơn nhưng địa vị cao hơn & Tôi & Danh tù thân tộc trên 'ego' \\
\hline
\end{tabular}


Nguyễn Quang (1992: 53) cũng lưu ý rằng: Trong truòng hợp cả hai đối tác tham thoại đều có thiện chi đạt tới tình thân hưu thì, tuỳ theo khoảng cách tuổi tác, 'Tôi' sẽ được thay thế bởi anh, chị, bác còn chức danh bởi em, cháu, con (đối với người nhiều tuổi hơn nhung địa vị thấp hơn) và 'Tôi' bởi em, cháu, con (đối với người it tuổi hơn nhung địa vị cao hơn). Truờng hợp sử dụng danh tù thân tộc ông, bà, cu hầu nhu không xảy ra ở đây vì nhũng ngườ đáng được sếp gọi là ông, bà, cu chắc chắn không còn làm việc nũa. Trong thục tế, quá trình "thân hữu hoá" này là quá trình chuyển tù khách quan tính sang chủ quan tính, tù sụ thoả hiệp trong xung hô sang "Quan hệ vòng"; và diều này, xét theo ngũ dụng, it nhiều tuoong tư nhu việc chuyển tù quan hệ chưc danh+tên ho (TLN) sang quan hệ tên riêng (FN) trong hệ thống xung hô Anh-Mĩ, hay tù " $V$ " sang " $T$ " trong các ngôn ngũ nói chung. với người kia (khách quan tính). Ví dụ, một nhân viên lúc đầu có thể nói với thủ trưởng của mình:

- Xin thủ trương cho tôi hai ngày để hoàn thành báo cáo này.

Nhưng sau một thời gian nhất định, cũng cùng một yêu cầu như vậy, người nhân viên ấy có thể nói:

- Xin thủ trương cho em hai ngày để hoàn thành báo cáo này.

Theo quan sát cá nhân, chúng tôi nhận thấy việc chuyển hình thức xưng hô theo kiểu này trong hoạt động giao tiếp giữa cấp dưới và cấp trên trong xã hội Việt được thực hiện khá chóng vánh. Nhiều khi người Việt bỏ qua giai đoạn 'Tôi-Chức danh' để tiến thẳng đến giai đoạn 'Em/Cháu-Chức danh' nhằm diễn tả sự thân mật xen lẫn tôn trọng trong quan hệ.

Kiểu quan hệ động này có thể được biểu diễn theo sơ đồ sau:

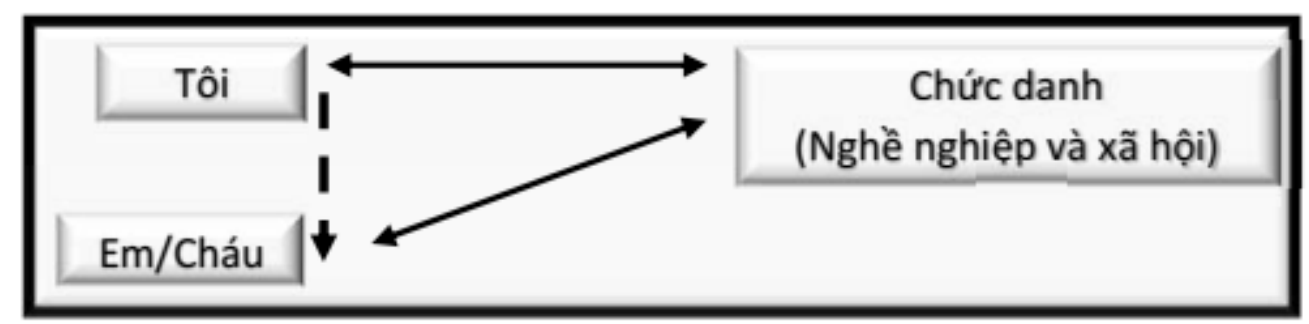

Hình 4. Quan hệ động-loại I trong xưng hô với người có địa vị cao hơn nhằm biểu thị sự thân mật nhưng tôn trọng

Cặp 'Tôi-Chức danh' (Quan hệ ngang-loại II), vốn được coi là mang tính khách quan cao nhất trong hệ thống xưng hô Việt, có thể tạo ra hai loại quan hệ mới mang tính chủ quan hóa (subjectivising) mà chúng tôi xin gọi chung là các 'Quan hệ động' (Dynamic Relationships/ Categories).

Trong cộng đồng ngôn ngữ-văn hóa Việt, sau một thời gian tiếp xúc, người ta có thể chuyển từ cặp 'Tôi-Chức danh' sang 'Cháu/ Em-Chức danh' để, một mặt, thể hiện sự hạ mình (self-abasement) và thân mật (chủ quan tính), mặt khác, vẫn giữ được khoảng cách
'Quan hệ động' cũng bao gồm một kiểu quan hệ trong đó yếu tố xung (Tôi) được giữ nguyên và yếu tố hô (Chức danh) bị thay đổi. Trong loại quan hệ này, vị trí chức danh của người nghe thường khiêm tốn (anh tài, anh bồi ...). Người Việt, vì lịch sự và tế nhị, thường tránh sử dụng chức danh của họ khi hô. Ví dụ: Khi vào quán giải khát, người Việt hầu như không nói:

- Này, cô hầu bàn, cho tôi hai nâu nhé.

Họ sẽ xét cô hầu bàn về mặt hình thức để đoán xem cô ta khoảng bao nhiêu tuổi và nên sử dụng hình thức xưng hô nào (thường là các hình thức xưng hô thuộc 'Quan hệ vòng' và 
đôi khi, thuộc 'Quan hệ ngang- loại I') cho phù hợp. Nếu người đó trạc tuổi con mình, người Việt có $\mathrm{xu}$ hướng dùng từ cháu/con thay thế cho chức danh, trạc tuổi em - dùng từ $e m$, trạc tuổi chị - dùng từ chị v.v. Kiểu xưng hô này mang tính 'nhấn nhá' vì nó, một mặt, vẫn giữ được tính trang trọng, khách quan (sử dụng 'Tôi' cho ngôi thứ nhất), mặt khác, vẫn tạo được sự thân mật, chủ quan (sử dụng danh từ thân tộc cho ngôi thứ hai). Ví dụ:

- Này, em ơi, cho tôi hai nâu nhé. gia đình, rồi dần dà được dùng giữa hàng xóm láng giềng với nhau và cuối cùng được mở rộng trong quan hệ thân hữu và giao tiếp xã hội. Nhìn chung, kiểu quan hệ xưng hô này được sử dụng phổ biến ở nông thôn hơn ở thành phố. Ví dụ:

- Bác cho em vay dăm cân gạo.

- Chú mà giúp chị thì chẳng đời nào chị lại quên ơn chú.

- Ông cho con hỏi tù đây về làng Đoài còn bao xa?

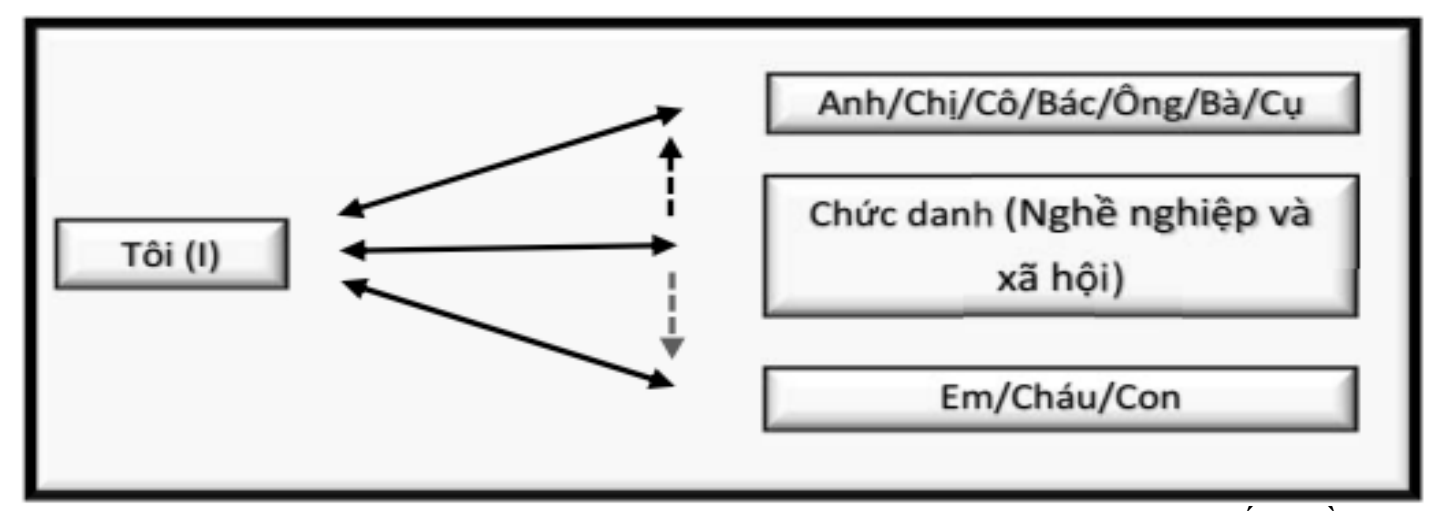

Hình 5. Quan hệ động-loại II trong xưng hô với người có vị trí chức danh thấp nhằm biểu thị sự tế nhị, tôn trọng và/hoặc thân mật

Tuy nhiên, các quan sát của chúng tôi gợi ra rằng nhiều người Việt thường đi xa hơn trong các biểu đạt nhân xưng chủ quan tính nhằm thể hiện sự thân mật, chân tình ở những kiểu tình huống này, đặc biệt, khi người nghe là nữ giới hay người già cả. Thay vì kiểu quan hệ động với cặp 'Tôi-Em' như trên, họ có xu hướng sử dụng 'Quan hệ vòng' với cặp 'AnhEm'. Ví dụ:

- Này, em ơi, cho anh hai nâu nhé.

Trong hệ thống xưng hô tiếng Việt cũng xuất hiện một kiểu quan hệ động mà, theo một số học giả nước ngoài, là một hiện tượng mang đậm hương vị 'hướng gia' (highly family-oriented) hay 'gia đình hóa' (familial) của người Việt. Đó là kiểu 'Gọi thay con' (Addressing on the child's behalf). Kiểu xưng hô này thể hiện sự thân mật, nhún nhường và 'tính gia đình' (familiality) rõ rệt. Khởi thuỷ, nó chỉ được sử dụng trong
Đây, suy cho cùng, cũng là một kiểu quan hệ động bộ phận như loại II vì người nói vẫn sử dụng hình thức xưng của mình trong quan hệ vòng và gọi người nghe theo hình thức hô mà lẽ ra con mình phải gọi người đó trong quan hệ vòng. 


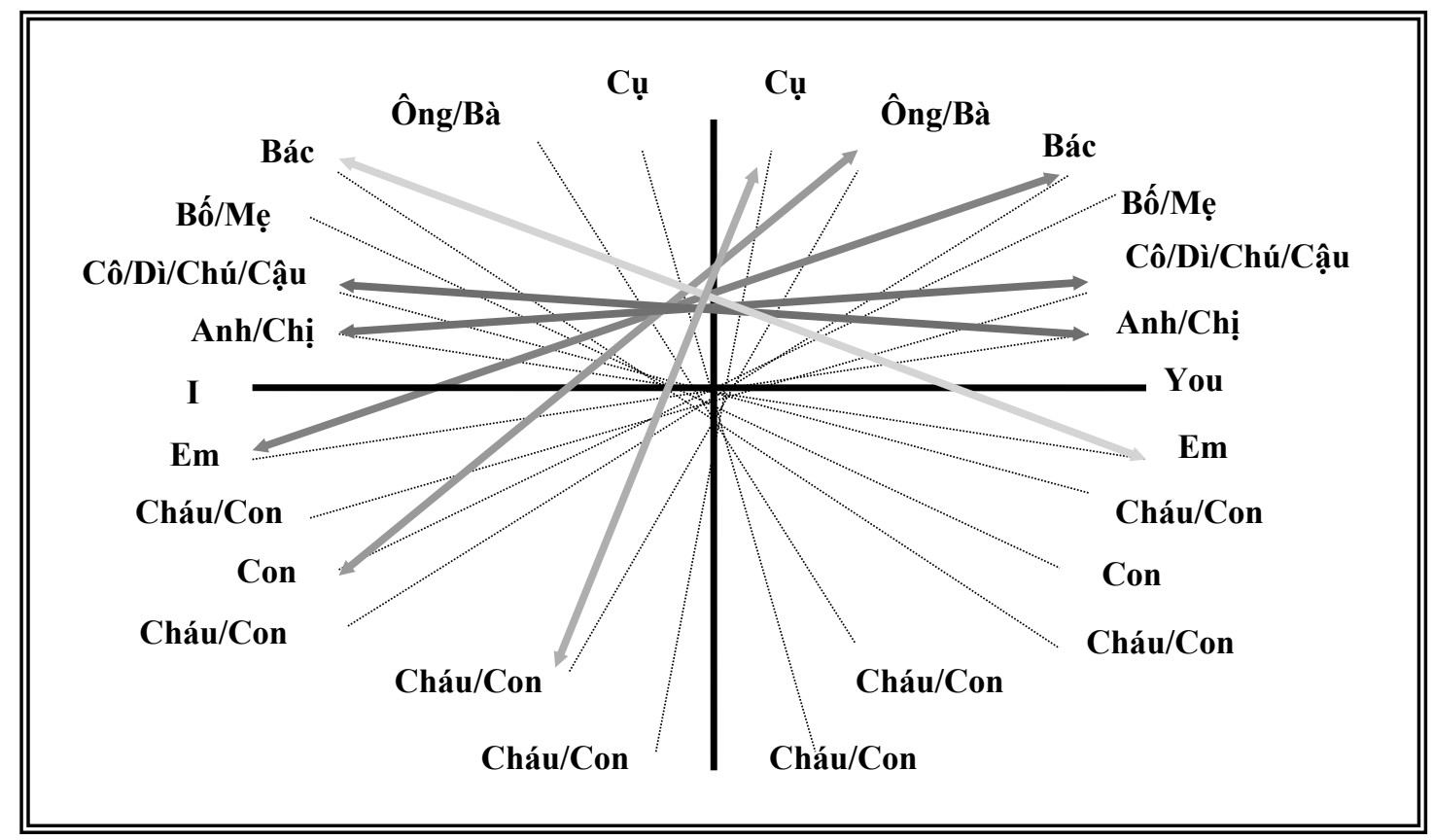

Hình 6. Quan hệ động-loại III của hình thức xưng hô tiếng Việt thể hiện sự thân mật, nhún nhường và tính gia đình

Ngoài kiểu 'Gọi thay con' bộ phận như vừa trình bày, người Việt còn sử dụng kiểu 'Gọi thay con' hoàn toàn; có nghĩa là nếu con mình phải dùng cặp nào trong quan hệ vòng để xưng hô với người khác thì họ cũng dùng chính xác cặp đó để chuyện trò với cùng đối tượng. Ví dụ: nếu nói chuyện với bố/mẹ của 'ego' thì con của 'ego' sẽ phải xưng cháu và hô $\hat{o n g} / b a ̀$. Theo kiểu 'Gọi thay con' hoàn toàn này, bản thân 'ego' cũng phải xưng cháu và hô ông/bà khi nói chuyện với bố mẹ mình. Trong thực tế, kiểu xưng hô này thường được sử dụng khi con của 'ego' còn nhỏ tuổi; và suy cho cùng, đây cũng là biến thể đối tượng của 'Quan hệ vòng'.

\section{Chủ quan tính và khách quan tính trong hệ thống xưng hô tiếng Anh}

Có người cho rằng, trong tiếng $\mathrm{Anh}$, chỉ với cặp trung tính I-YOU (neutral dyad $I-Y O U)$, một cặp xưng hô khách quan và phi biểu cảm, phi biểu thái, ta có thể chuyện trò với mọi người mà không cần xét đến tuổi tác, giới tính, địa vị xã hội của đối tác giao tiếp, quan hệ giữa người nói và người nghe, thái độ và tình cảm mà người nói cần biểu đạt, ... Tuy nhiên, trong thực tế, vấn đề không đơn giản như vậy. Ngoài quan hệ xưng hô I-YOU mang tính khách quan gần như tuyệt đối (nếu tách khỏi các yếu tố nội ngôn, cận ngôn và ngoại ngôn đi kèm), trong tiếng Anh còn tồn tại nhiều hình thức xưng hô khác mà việc sử dụng chúng nhằm thể hiện các cung bậc chủ quan tính với các mức độ tình cảm và thái độ khác nhau tỏ ra không mấy dễ dàng. Về cơ bản, hệ thống xưng hô tiếng Anh bao gồm các hình thức sau:

* Chức danh (Title alone-T): bao gồm:

- Chức danh nghề nghiệp (Career title-CT): Ví dụ, Professor [Giáo sư], Doctor [Bác sĩ], Boss [Sếp] ...

- Chức danh xã hội (Social title-ST): Ví dụ, Mr. [Ông], Miss [Cô], Sir [Ngài] ...

- Chức danh xã hội + Chức danh nghề nghiệp (Social title + Career title): Ví dụ, Mr. President [Ngài Tổng thống], Mr. Chairman [Ngài Chủ tịch] ... 
* Chức danh + Tên họ (Title with last name-TLN): Ví dụ, Professor Browning [Giáo sur Browning], Mr. Clinton [Ông Clinton]...

* Tên họ (Last name alone-LN): Ví dụ, (John) Nixon, (Mary) King...

* Tên riêng (First name-FN): bao gồm:

- Tên riêng (First Name): Ví dụ, $\underline{\text { John }}$ (Nixon), Mary (King) ...

- Tên riêng rút gọn (Diminutive): Ví

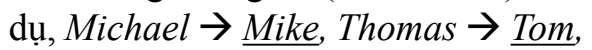
Elisabeth $\rightarrow \underline{\text { Liz } \ldots . .}$

- Tên riêng rút gọn $+\mathrm{y} / \mathrm{a}$ (Diminutive+y/a): Ví dụ, Tom $\rightarrow$

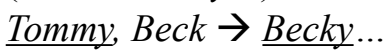

* Đa danh (Multiple names-MNs): Theo cách giải thích của Brown và Ford (1964:238), 'Đa danh' có nghĩa là khi nói chuyện với cùng một đối tượng, "lúc thì ta dùng chức danh + tên họ, khi thì ta dùng tên riêng hay tên ho hoặc biệt danh, có khi lại tạo ra nhũng biến thể ngũ âm hoặc của tên riêng hoặc của biệt danh." Đa danh trong thực tế cũng tồn tại trong tiếng Việt và thường được sử dụng trong quan hệ rất thân mật, giống như trong tiếng Anh. Ví dụ: ta có một người bạn thân tên là Lê Hùng Tiến. Tùy tình huống, có lúc ta gọi anh ta là Phó giáo su Lê Hùng Tiến, có lúc lại nói Tiến, có khi lại gọi Tiến Toác, có lúc lại nói lái thành Tiền Toạc...

* Danh từ thân mật (Term of endearment$\boldsymbol{T E}$ ): Ví dụ: Honey [Mật ngọt], buddy [ông bạn], sweetie [bé yêu], babe [bé] ...

* Danh từ thân tộc (Kinship term-KT): bao gồm:

- Danh từ thân tộc (Kinship term): Ví dụ: Aunt [Cô/Dỉ], uncle [chú/bác] ...

- Danh từ thân tộc $+\mathrm{y}($ Kinship term + y): Ví dụ: Daddy, aunty, mommy ...

* Danh từ thân tộc + Tên riêng (Kinship term + First name $-\boldsymbol{K T}+\boldsymbol{F N}$ ): Ví dụ: Aunt Susan [Cô Susan], uncle Tom [bác Tôm] ...

Tuy vậy, trong giao tiếp xã hội, thông thường chỉ tồn tại hai hình thức lựa chọn chính: 'Tên riêng' và 'Chức danh + Tên họ'. Theo Brown và Ford (1964), Ervin-Tripp (1972), Wardhaugh (1986) và nhiều nhà nghiên cứu khác, 'Tên riêng' có thể tương đương với hình thức ' $T$ ' (thân mật) và 'Chức danh + Tên họ' - với hình thức 'V' (tôn trọng). Vì vậy, trong tiếng Anh, khi muốn biểu thị 'ngữ nghĩa thân hữu' (solidarity semantic), hay nói cách khác là muốn tỏ ra thân mật, người Anh-Mĩ-Úc thường gọi đối thể giao tiếp bằng 'Tên riêng' của người đó; và khi muốn viện tới 'ngữ nghĩa quyền lực' (power semantic) hay muốn tỏ ra trang trọng, tôn trọng với ít nhiều 'xa cách', họ thường dùng 'Chức danh + Tên họ' để gọi đối thể giao tiếp.

Hai hình thức 'Tên riêng' (gồm cả FN, D và $\mathrm{D}+\mathrm{y} / \mathrm{a}$ ) và 'Chức danh + Tên họ' (gồm cả $\mathrm{CT}+\mathrm{LN}$ và $\mathrm{ST}+\mathrm{LN}$ ) được chia thành 3 nhóm quan hệ:

1. Trao đổi 'Tên riêng' qua lại (Mutual exchange of $F N$ ).

2. Trao đổi 'Chức danh + Tên họ' qua lại (Mutual exchange of TLN).

3. Trao đổi 'Chức danh + Tên họ' và 'Tên riêng' một chiều (Nonreciprocal exchange of $T L N$ and $F N$ ) trong đó một người (già hơn, có địa vị cao hơn...) gọi người kia bằng 'Tên riêng' và được người kia gọi bằng 'Chức danh + Tên họ'.

Chủ quan tính và khách quan tính trong các hình thức xưng hô này, theo Wardhaugh (1986), được biểu đạt như sau:

- Việc sử dụng quan hệ 'Chíc danh + Tên ho - Tên riêng' chỉ ra sự bất bình đẳng về quyền lực;

- Quan hệ 'Chíc danh + Tên họ qua lại' biểu thị sự bình đẳng và không gần gũi;

- Quan hệ 'Tên riêng qua lại' cho thấy sự bình đẳng và gần gũi giữa hai đối thể giao tiếp.

Khi nghiên cứu về hệ thống xưng hô tiếng Anh Mĩ, Brown và Ford (1964) đã nhận xét rằng hai kiểu quan hệ qua lại ('Chức danh + Tên họ qua lại' và 'Tên riêng qua lại') đều bị chi phối bởi một bình diện đơn nhất bắt đầu bằng sự quen biết và kết thúc bằng sự thân mật. Nếu hai đối tác giao tiếp chỉ là chỗ quen biết, họ sẽ gọi nhau bằng 'Chức danh + Tên 
họ' và cũng trông đợi người kia gọi mình như vậy. Nhưng nếu là chỗ bạn bè, họ sẽ xưng hô với nhau bằng 'Tên riêng'.

Rõ ràng, việc sử dụng 'Chức danh + Tên họ’ qua lại đã trở thành một hình thức lịch sự (âm tính) trong giao tiếp xã hội với tính biểu thái thấp. Nhưng cũng theo Wardhaugh (1986), trong hệ thống xưng hô Anh-Mĩ, việc sử dụng 'Tên riêng' qua lại nhằm biểu thị tình bằng hữu đã dần dần thay thế việc sử dụng 'Chức danh + Tên họ' qua lại vốn diễn tả thái độ lịch sự (âm tính) trong các quan hệ cá nhân. Tuy nhiên, tác giả (1986: 260) cũng lưu ý, ... việc dùng tên riêng của một người [...] không nhất thiết là để biểu thi tình bằng hữu hay sự thân mật. Tên riêng được sủ dụng giũa nhũng người làm việc gần gũi với nhau, mắc dù họ có thể chẳng thích thú gì nhau. Tên riêng thậm chí còn có thể được sư dụng để gọi các nhân vật chính khách, hoặc với thái độ khinh bỉ hoặc với tinh cảm nguỡng mộ.

Vì vậy, trong nhiều hoàn cảnh, trong đó người Việt sử dụng quan hệ trao đổi không qua lại tương đương với quan hệ 'Chức danh + Tên họ - Tên riêng' trong tiếng Anh (ví dụ: 'Quan hệ động - loại I', 'Quan hệ vòng' với xưng bậc thấp và hô bậc cao) thì người Mĩ hiện đại lại có xu hướng sử dụng quan hệ 'Tên riêng qua lại'. Thậm chí đối với cả tổng thống, một người dân Mĩ bình thường cũng có thể gọi ông ta bằng tên riêng (và đây chính là sốc văn hoá tiềm năng đối với người Việt học tiếng Anh, đặc biệt là tiếng Anh-Mĩ).

Thực tế này, xét theo điểm qui chiếu của tính biểu hiện (manifestability), đã gây ra khá nhiều phiền phức trong các tương tác liên văn hoá Việt-Mĩ. Người Mĩ vốn được cho là ít thích trang trọng, hình thức nên dễ dàng chuyển nhanh sang kiểu quan hệ 'Tên riêng qua lại' và điều này đã gây sốc cho nhiều người Việt, đặc biệt là những người trung niên và cao niên, hay các quan chức mà, xét về chức danh, ở địa vị cao hơn người Mĩ đang nói chuyện với họ. Họ cho rằng người Mĩ ngạo mạn, trịch thượng và không tế nhị. Ta không loại trừ khả năng này trong những trường hợp cụ thể, nhưng trong rất nhiều trường hợp, người Mĩ hoàn toàn có thiện chí muốn tạo ra sự thân mật và tình bằng hữu khi sử dụng quan hệ 'Tên riêng qua lại'.

Với loại 'Quan hệ Chức danh + Tên họ Tên riêng không qua lại' (Nonreciprocal TLNFN relationship), ảnh hưởng của quyền lực đã được Brown và Gilman (1962) giải thích theo cách nhìn nhận của phân tâm học. Họ cho rằng quyền lực mà cha mẹ có được đối với con cái đã ngăn cản không cho chúng xưng hô với những người bằng tuổi hoặc già hơn cha mẹ chúng một cách suồng sã. Điều này có thể thậm chí còn là cội nguồn của việc sử dụng 'Chức danh + Tên họ - Tên riêng' với những người có quyền lực chính trị hoặc xã hội, vì họ, suy cho cùng, cũng là những 'nhân vật cha chú' (parent figures).

Ngoài ảnh hưởng của hai bình diện tuổi tác và địa vị trong việc quyết định cách thức sử dụng 'Quan hệ Chức danh + Tên họ - Tên riêng không qua lại', chúng ta cũng cần xét đến bình diện giới tính. Theo Fasold (1990:30),

Xét về mặt truyền thống, it nhất, nếu có một kiểu quan hệ không qua lại trên cơ sở giới tinh thì chinh phu nũ sẽ được tiếp nhận hình thức xung hô trang trong hơn.

Nói cách khác, khi phụ nữ và nam giới cùng chuyện trò và lúc đó hoàn cảnh đưa đẩy tới sự xuất hiện 'Quan hệ Chức danh + Tên họ - Tên riêng không qua lại’ thì chắc chắn phụ nữ sẽ tiếp nhận hình thức 'Chức danh + Tên họ' (TLN) và nam giới sẽ được gọi bằng 'Tên riêng' (FN). Ví dụ: cô Mary Snow (Miss Mary Snow) nói chuyện với anh John Goodman (Mr. John Goodman). John Goodman sẽ gọi Mary Snow là 'Miss Snow' (Cô Snow) và cô Snow có thể gọi John Goodman đơn giản là 'John' hoặc thậm chí 'Johny'. Đây phải chăng là ảnh hưởng của phong cách 'Gentleman' (Quân tử phương Tây) tôn trọng phụ nữ trong xã hội Anh truyền thống (chí ít cũng là ở tầng lớp trên)? 
Brown và Ford (1964) nhận xét rằng với người Mĩ thì chỉ cần nói chuyện trong năm phút là đủ để chuyển từ kiểu 'Quan hệ Chức danh + Tên họ qua lại' sang kiểu 'Quan hệ Tên riêng qua lại’. Nhưng Fasold (1990) lại tin rằng thậm chí cũng không cần đến năm phút nếu một cơ sở tương đối bền vững nào đó cho tình thân hữu (ví dụ: buổi gặp gỡ đầu tiên giữa các đồng nghiệp, lần nói chuyện đầu tiên giữa hàng xóm cũ và mới ...) bắt đầu xuất hiện.

Khi giận dữ hoặc lúc trách cứ, ngoài các thủ pháp nội ngôn, cận ngôn và ngoại ngôn, trong tiếng Anh, người ta còn sử dụng hình thức xưng hô để diễn tả thái độ chủ quan của mình bằng cách chuyển từ hình thức sử dụng tên riêng sang hình thức sử dụng chức danh + tên họ. Theo Fasold (1990: 25),

Nếu người ta giận dũ với ngườ mà ho thuờng gọi bằng tên riêng, ho sẽ rút về cách sư dụng chức danh + tên ho để chứng tỏ sư đứt quãng trong quan hệ. Khi vấn đề gây ra phiền phưc được giải quyết, ho lại trở về với việc sư dụng tên riêng.

Như đã được đề cập ở trên, chức danh $(\mathrm{T})$ là một khả năng khác được sử dụng để xưng hô với mọi người. Qua tham khảo một số bạn bè và đồng nghiệp Mĩ, chúng tôi cho rằng hình thức xưng hô này và hình thức chức danh + tên họ nhìn chung không có gì khác nhau: Chúng đều hoặc được sử dụng một cách qua lại giữa những người mới quen biết trong môi trường mà tính trang trọng còn đang khống chế, hoặc được sử dụng một chiều bởi một người có địa vị thấp hơn với một người có địa vị cao hơn. Tuy nhiên, Wardhaugh (1986:262), xét theo mức độ biểu thái của chủ quan tính, lại nhận định rằng:

Xung hô bằng chức danh là hình thức xung hô it thân mật nhất bởi chức danh thuờng xác định vị trí chức vu và nghề nghiệp, nhu: đại tá, bác sĩ hoặc anh bồi. Chúng không mang nội dung 'riêng tu'. Do đó, chúng ta có thể cho rằng 'Bác sĩ Smith' nghe thân mật hơn 'Bác sĩ', vì rõ ràng là tên của người kia đã được biết đến và có thể đurợc đề cập.
Về việc sử dụng tên họ trong xưng hô, Levine và Adelman (1982) nhấn mạnh rằng, trừ trường hợp đặc biệt, còn thông thường, tên họ luôn đi kèm với chức danh. Việc sử dụng tên họ thuần tuý được cho là ít trang trọng hơn chức danh + tên họ nhưng lại không thân mật bằng tên riêng.

Cùng quan điểm với Fasold (1990), Brown và Ford (1964) cũng chỉ ra rằng tên họ thường được dùng để gọi những người mà ta hiếm khi gặp; và trong những tình huống mà ở đó tên họ không phải là hình thức thường dụng cho người được gọi thì nó tạo ra một mức độ thân mật cao hơn chức danh+tên họ nhưng thấp hơn tên riêng.

Khi xem xét việc sử dụng đa danh (MNs), người ta dễ dàng thống nhất rằng đa danh tạo ra mức độ thân mật cao hơn so với tên riêng, nhưng rõ ràng là các mức độ thân mật không phải dễ dàng có thể đo đếm được. Fasold (1990) cho rằng đa danh không dùng để diễn tả sự giận dữ; nó được sử dụng với các sắc thái ít nhiều mang tính tự do. Vì vậy, việc sử dụng đa danh đối với thậm chí cả người bản ngữ cũng không phải là dễ dàng. Việc dùng chức danh + tên họ và tên họ trong xưng hô đa danh không nên hiểu là mang sắc thái trang trọng và xa cách.

Trong tiếng Anh cũng xuất hiện cái mà chúng tôi xin được gọi là 'Address-form avoidance - AFA' (Nói trống không). Kiểu xưng hô này trong tiếng Việt thường bị qui gán là tiêu cực, đặc biệt là khi người nói ít tuổi hơn và/hoặc ở vị trí thấp hơn so với người nghe. Trong thực tế, nhìn chung, nói trống không trong tiếng Anh có tần suất sử dụng cao hơn trong tiếng Việt và không bị gán ghép nặng nề với khái niệm 'thiếu văn hoá' hay 'thiếu giáo dục' như ở ngôn ngữ-văn hoá Việt. Nếu trong tiếng Việt, xét theo chuẩn mực xã hội, 'Nói trống không' chỉ có thể, ở các mức độ khác nhau, được chấp nhận qua lại giữa những người đồng niên, đồng quyền (age-equals and power-equals) và được sử dụng ít nhiều thoải mái hơn với người ít tuổi hơn và/hoặc có địa 
vị thấp kém hơn thì trong tiếng Anh, đặc biệt là tiếng Anh-Mĩ, tình hình không đến nỗi ngặt nghèo như vậy. Theo Wardhaugh (1986), trong tiếng Anh-Mĩ, khi người ta chưa biết phải xưng hô với nhau thế nào, họ có thể không sử dụng hình thức xưng hô. Ví dụ: thay vì nói 'Good morning, Mr. Smith' (Chào ông Smith), ta chỉ cần nói 'Good morning'. Wardhaugh (1986) cũng cảnh báo rằng ở nhiều ngôn ngữ khác, kiểu nói trống không như vậy có thể bị qui kết là bất nhã hay bất cập. Tiếng Việt là một ví dụ.

\section{Kết luận}

Có thể khẳng định rằng các hệ thống xưng hô nói chung, hệ thống xưng hô Việt và Anh nói riêng, đều có các hình thức/cặp xưng hô biểu đạt chủ quan tính và khách quan tính ở các mức độ khác nhau. Do vậy, khi tiến hành nghiên cứu dụng học giao văn hóa về chủ quan tính-khách quan tính trong việc sử dụng các hình thức/cặp xưng hô trong các sự kiện, tình huống giao tiếp cụ thể, câu hỏi chính yếu đặt ra không phải là các hình thức/cặp xưng hô trong hai cộng đồng được đối sánh có thể hiện tính chủ quan và tính khách quan không, mà là liều lượng biểu đạt chủ quan tính và khách quan tính trong các hình thức/cặp xưng hô được sử dụng trong các sự kiện, tình huống giao tiếp đó thế nào, cách thức biểu đạt ra sao và lực ngữ dụng (lực ngôn trung và lực ngôn tác) của các biểu đạt đó là gì. Và nếu có thể đi xa hơn, các câu hỏi tiếp theo sẽ là các thành tố giao tiếp nào đã tác động đến việc lựa chọn các hình thức/quan hệ xưng hô đó [giao tiếp] và các ẩn tàng văn hóa nào đã ảnh hưởng đến sự lựa chọn này [văn hóa].

\section{Tài liệu tham khảo}

\section{Tiếng Việt}

Nguyễn Tài Cẩn (1975). Tù loại danh tù trong tiếng Việt hiện đại. Hà Nội: NXB Khoa học Xã hội.

Nguyễn Quang (1999). Một số khác biệt giao tiếp lời nói Việt - Mĩ trong cách thức khen và tiếp nhận lời khen.
Không xuất bản. Trường Đại học Khoa học Xã hội và Nhân văn - Đại học Quốc gia Hà Nội.

\section{Tiếng Anh}

Brown, R.W. and Ford, M. (1964). Address in American English. In Hymes (ed.). Language in Culture and Society. Harper and Row.

Brown, R. and Gilman, A. (1962). The Pronouns of Power and Solidarity. American Anthropologists, 4(6): 24-9.

Ervin-Tripp, S. (1972). Sociolinguistics. In Pride and Holmes, 1972: 225-40. Excerpt from Ervin-Tripp.

Fasold, R. (1990). The Sociolinguistics of Language. Basil Blackwell.

Hughson J (2009). Diversity and Changing Values in Address: Spanish Address Pronoun Usage in an Intercultural Immigrant Context. Frankfurt am Mein: Peter Lang.

Lambert, W. and Tucker, G.R. (1976). Tu, Vous, Usted: a Social-Psychological Study of Address Patterns. Rowley, MA: Newbury House.

Levine, D.R. and Adelman, M.B. (1982). Beyond Language - Intercultural Communication for English as a Second Language. Prentice Hall Inc.

Muehlhaeusler P and Harre R (1990). Pronouns and People: The Linguistic Construction of Social and Personal Identity. Oxford, MA: Basil Blackwell.

Nguyen Quang (1991). Subjectivity and Objectivity in English and Vietnamese. Paper presented at the International Conference on Education and Language Development. Ho Chi Minh City, Vietnam.

Nguyen Quang (1992). Some Australian-Vietnamese Cross-Cultural Differences in Conveying Good and Bad News. Unpublished. University of Canberra. Australia.

Richards, J.C. and Sukwiwat, M. (1986). Cross-Cultural Aspects of Conversational Competence. Cambridge: CUP.

Robinson, W.P. (1972). Language and Social Behaviour. Harmondsworth, England: Penguin Books.

Stitz, G. (1992). The Use of the First Name in the Australian Context. ALAA Conference, 1992. Sydney, Australia.

Szyman'ska-Matusiewicz, G. (2014). The researcher as 'older sister', 'younger sister' and 'niece': playing the roles defined by the Vietnamese pronominal reference system. In Qualitative Research, 14(1): 95-111.

Wardhaugh, R. (1986). An Introduction to Sociolinguistics. Basil Blackwell. 


\title{
SUBJECTIVITY AND OBJECTIVITY \\ IN VIETNAMESE AND ENGLISH ADDRESSING SYSTEMS
}

\author{
Nguyen Quang \\ VNU University of Languages and International Studies, \\ Pham Van Dong, Cau Giay, Hanoi, Vietnam
}

\begin{abstract}
In this article, working definitions of subjectivity and objectivity are offered, and $\mathrm{T}-\mathrm{V}$ paradigm of addressing terms/dyads in languages discussed. Expressions of subjectivityobjectivity in Vietnamese and English addressing systems are critically analysed on the basis of primary and secondary sources.

Keywords: subjectivity, objectivity, addressing term/dyad, addressing relationship
\end{abstract}

